\title{
Representation of authors' worldview in selected poems of Mabala, Summons: poems from Tanzania (A genetic structuralism analysis)
}

\author{
1,2Astelia Mihayo \\ IIda Bagus Putera Manuaba* \\ ${ }^{1}$ Department of literary and cultural Studies, Universitas Airlangga, Indonesia \\ ${ }^{2}$ Language and Literature Unit, Mkwawa University College of Education, Tanzania
}

*Corresponding Author

Email: ibputeramanuaba@gmail.com

\begin{abstract}
This paper examines the worldview of Tanzanian poetry in English. It focuses on selected poems of Mabala (1980) entitled Summons: Poems from Tanzania. The study places the poems under Lucien Goldmann's genetic structuralism approach and argues against the historical context and discourse of Tanzania between 1960s and 1980's. Specifically, the study analyses the author's social and historical conditions influenced the production of the Summons poetry and showcases how the author's worldview in particular poems in general are creatively explored in the social realities. The exploration of worldview in selected poems congruence the social and historical realities and the Socialism ideology [society's worldview or global structure]. In other words, the exploration of the worldview in the selected poems confirms the homology of the global structure. The poems construct the ideal values of socialist state that seemed relevant in the post-independence Tanzania. They, in one or another provide the historical account for the building of Socialism ideology. They are about and against the ideology which confuse the vision people have of themselves and of their lives and the friction that failed the implementation of Socialism ideology. The study appropriates dialectic method to achieve the coherence of meaning of the text as a whole (poem structure and global structure).
\end{abstract}

Keywords: Author's worldview; genetic structuralism; socialism; Summon poetry

Received: $\quad$ Revised:

17 March 201927 August 2019

Accepted: $\quad$ Published:

27 August $2019 \quad 31$ August 2019

\section{INTRODUCTION}

Literature is a mirror of the society, such as reflection of the author's life, society, experience and his or time. In fact, author as the part of the society expresses his or her society's social and historical events through his creativity, namely literary work (Endraswara, 2013). It is widely acknowledged that the literary work is not a brilliance creation of the individual rather is grounded upon the transindividual mental structures belonging to a particular social class or group (Goldmann, 1980; Selden et al., 2016). 
Mihayo, Manuaba, EduLite: Journal of English Education, Literature, and Culture Vol.4, No.2, August 2019, 171-182 DOI: http://dx.doi.org/10.30659/e.4.2.171-182

Therefore, literary work or text is regarded as a social and historical document that uses language as medium to signify social reality (Witri Nur'aini, 2009).Indeed, it records and reveals all the social and historical features in which it was fashioned. Similarly, the social and historical milieu influence the production of particular literary text (Zubaidi, 2011). Laurenson \& Swingewood (1972) further describes that it is important to place a literary text in its historical space and time in order to sufficiently provide the meaning in modern times. Thus, the text should be authentically analysed and interpreted based on its context of production. Because such contexts add value to the understanding and interpretation of text's meaning.

Laurenson \& Swingewood ( 1972) claims that literature is concern with people's life and thus is a cultural history. In this sense, it should be analysed with reference to history as means of understanding history, customs, norms, race, politics and various social concerns that pertains a particular society in particular historical period. For instance, Animal Farm an allegorical novella by George Orwell published in 1945 in England. The novella showcases the events leading up to the Russian Revolution of 1917 and then on into the Stalinist era of the Soviet Union. Orwell described Animal Farm as a satirical tale against Stalin. Also, Iron Star novel written by Brian Kelleher gives a picture of the social condition in America during the end of the World War II.

The authors of these two novels through the choice of characters have tried to fuse political and artistic purpose into one whole. Henceforth the structure of the texts reflects the context of their production such as Socialism Russia and World War II in America predominantly. As Eagleton argues that, "the text comes to be what it is because of the specific determinations of its modes of productions" (Eagleton, 1983, p. 48) that shows how social, political, and economic structure of the society are organized. He also asserts that, "literary texts in some sense internalizes its social relations of production, (...] encodes with itself its own ideology of how, by whom, and of whom it was produced" (Eagleton, 1983, p. 48), thus Eagleton look at Art as a critical discourse inseparable from society and the ideological stand of that particular society. It is for this reason the study focuses on selected poems from Tanzania edited by Richard Mabala (1980) entitled Summons (Poems from Tanzania).

I argue for the use of Summons poetry to trace the relationship between literature and its history of production and how the two poles fuse to form meaning [worldview] expressed by the poets. Goldmann (1980) demonstrates that worldview is a structure of ideas, aspirations, and feelings which serve to unite a social group vis-à-vis other social group. It is not an individual view, but however it is a view of his society (social group or class). Accordingly, literary works being the product of the society bears coherence with the worldview [ideology] of the society in which it was produced. Alongside, the author as part of the society, he then represents the collective view of his society through his imaginative work of art.

On the other hand, Summons is anthology that was written in postindependence Tanzania, during and after the Socialism ideology respectively. The poets in this collection are Tanzanian brought in the ferment of the policy of Socialism and Self-reliance (Mabala,1980).Thus, poems from Summons discourses complications of building socialism. Precisely, they are about and 
contrary to the socialism ideology (Mabala, 1980). Precisely, Summons provide visions of the Socialism ideology and its operation in between 1960s and 1980s.

In consideration of its inauguration in 1967 Socialism ideology has captivated copious scholars and prominent writers. So far there is a plenty of published and unpublished works on the late Julius Kambarage Nyerere who was the first president of the United Republic of Tanzania and the founder and advocate of the socialism philosophy in 1960s and the Ujamaa ideology [policy] in Tanzania. Ibhawoh and Dibua (2003) asserted that several scholarly works and also works from renowned writers appeared particularly in the 1970s when the transformations in Tanzania captured world attention, leading to the debate about the avail and drawbacks of the Ujamaa operation. Hence, the discourse of Ujamaa became a thriving industry for academics and popular writers (Ibhawoh \& Dibua, 2003).

On the other hand, literary response to the ideology of Ujamaa entered both English and Swahili literature in Tanzania. However, Tanzanian poetry in English has not been a subject of priority and thus it is not yet engrossed numerous scholars in the literary field. Mwaifuge and Omigbule (2016) also asserted that most of scholars in poetry centre more extensively on published Kiswahili poetry. Notably with only few studies done so far in Tanzanian poetry in English their focus was on how language creates meaning in Tanzanian cultural setting. While in Ujamaa ideology their focus has been on telling the national history (Yona, 2008). This study however focuses on Summons to critically analyses the authors' worldview in selected poem, specifically how poetry exploration echoes the social and historical condition of its production. This is achieved by placing the poems in their historical settings, reading them against the discourse of Ujamaa ideology. Precisely, how is the social and historical background of authors' society influenced the creation of Summons poetry?

\section{METHOD}

The study deployed qualitative approach guided by Lucien Goldmann's genetic structuralism theory to explore the worldview (social and historical meanings) ascribed in Summons poetry across space and time. The study considers Berg (2012) and Creswell (2013) assertion that qualitative approach is primarily concerned with interpretation of the meanings, concepts, definitions, characteristics, metaphors, symbols, and description of things or human experience.

\section{Data Collection}

This study largely uses primary data from the selected poems, Summons. In collecting primary data pertaining to the exploration of worldview I focus on the words, phrases and language that describe the process of building Ujamaa, implementation and problems brought out by the socialism ideology between 1960s and 1980s as portrayed in the poems. Deliberately, I focus on the way language of the poems communicates memories of the ideology and its problems. The study also uses secondary data to supplement primary data. These includes literary books, journal articles, previous thesis and other useful sources to the study. 
Mihayo, Manuaba, EduLite: Journal of English Education, Literature, and Culture Vol.4, No.2, August 2019, 171-182 DOI: http://dx.doi.org/10.30659/e.4.2.171-182

\section{Data analysis}

The study largely involves textual analysis in interpreting and describing the worldview of the selected poems. The study uses textual analysis as a central method to critically analyse worldview of the author as a part of the society in which the poems were created through the artic use of language employed in Summons. Indeed, this study follows what Belsey (2013) argues for textual analysis methods in the study of humanities as important to understand the ascription of meaning in its artefacts. The analysis of data was guided by genetic structuralism approach. Thus, the study used dialectic method to attempt the objectives of the study because it aims to achieve the coherence of meaning between the text structure and that of the society.

\section{Procedures}

For critical analysis of worldview of the selected poems, two procedures were used in attempting to find out the worldview of Summons poetry.

At first, the study places selected poems under close reading. The hypothesis under this method is that the text under study is self-enclosed and self-sustaining entity (Laurenson \& Swingewood, 1972). So, approaching Summons to find out the ways in which socialism (worldview) is represented I paid close attention to the text itself with no consideration to external factor. The study considers Rivkin's and Ryan's argument that close reading explicate the ways in which "literature embodies or concretely enacts universal truth" (Rivkin \& Ryan 2004, p. 6) through language that is interpreted denotatively or connotatively (Ng'umbi, 2015).

Secondly, the study places selected poems in the contexts that influenced their production. As pointed out earlier the text under study is shaped by socialism ideology, therefore, the selected text is read with reference to the socio-historical factors surrounding its production. In a point of fact here I find the meaningful interaction between internal structures of the texts [language of the text] and the contexts of its production. Laurenson ans Swingewood (1972) demonstrated that literature cannot distant itself from the society and context that created it. Thus, Summons cannot distance itself from socialism ideology. Accordingly, as a researcher I argue to translate the internal structure of the text and the context [society] into public meaning: order to translate the text with insights in context to examine the worldview of the poems under study.

\section{RESULTS AND DISCUSSION}

\section{Social and historical conditions influencing the creation of Summons poetry}

Just like a colonial history of other African countries informs, Tanzania Mainland (Tanganyika in the pre-1964 Union period) was colonized by the German before it later was by the Britons (Mwaifuge \& Omigbule, 2016). Whilst Tanzanian island of Zanzibar had been colonized by the Arabs. Accordingly, Tanzania got independence in 1961 under the leadership of the first president Julius Nyerere. He was also the leader and founder of TANU (Tanganyika African National Union). Thus in 1954 TANU became the ruling 
party in what was then called Tanganyika before it merged with Zanzibar to form Tanzania in 1964. In both places, colonialists exploited resources and left nothing rather than poverty. It is during this post independence period when Tanzania experienced a great economic crisis. Yona $(2008$, p.14) pointed out that a few years later after independence, Nyerere discovered that there were needed drastic changes to be introduced to revamp the economic situation. He continued by arguing that, Nyerere wanted Tanzania to be selfreliant so that people could enjoy the fruits of independence (Yona, 2008). As Nyerere argued that, "independence cannot be real if a nation depends upon gifts and loans for its development" (Nyerere, 1968, p.239).Then, on post independent, Tanzania adopted Ujamaa (socialism) so as to overcome the economic depression that the country had faced (Mkunde, 2014;Wakota, 2014). The African Socialism (ujamaa) was based on:

Establishment of socialist villages [Ujamaa Vijijini] that sustain equality for all people. Wakota $(2014$, p.4) stated that Ujamaa identified itself by appealing to "an idealized construction of traditional African forms of kinship and extended family - one that emphasized reciprocity, collective effort, and an open version of community"; ..... "registered a type of family hood characterized by connection and fluidity". This means that the philosophy attempted to bring people to return to the pre-colonial moral economy through the communal organization and control of production (Sheikheldin, 2015; Wakota, 2016; Yona, 2008) For Nyerere the Ujamaa philosophy was more appropriate for all newly- independent African states. Of its central objectives, rural development or villagization to empower people economically became one of the projects to be achieved in due course of building socialist state. Indeed, villagization under Ujamaa philosophy was both a resettlement and production project, through which villages were to become schemes in which people lived and worked communally (Wakota, 2016).

The Ujamaa philosophy also advocated for education for self-reliance. The main argument put forward was that the education system introduced by the colonialists did not address the needs of the Tanzanian people. Thus, it was advocated that there was a need to introduce an education system that would be more culturally relevant to the Tanzanians and it should be used to solve the needs of the society unlike the colonial education system. Education for self-reliance was a right for every member in the society and every individual who become educated was supposed to serve and liberate the whole society. This education for self -reliance together with other principles of the Ujamaa advocated the traditional African values and principles of communalism, collective production, egalitarian distribution, and universal obligation to work in order to create non-exploitative society (Ibhawoh \& Dibua, 2003; Lal, 2010; Makulilo, 2012). The Ujamaa philosophy was rooted in traditional African values and had as its core the emphasis on "family hood" and communalism of traditional African societies. It also had essentially built itself around creation of equal, free and unified societies. So, the policy or ideology aimed at developing the country and building of socialism (Yona, 2008). All the strategies that were to be applied should first and most importantly meet the needs of poor Tanzanians and also help in the building of socialism. Self-reliance policy was seen as the policy that would help in the building of socialism and developing the country. 
Mihayo, Manuaba, EduLite: Journal of English Education, Literature, and Culture

However, Ujamaa was both essential and dubious policy which provoked a variety of responses from the people. For example, many people in the rural areas were reluctant to move in new villages and were not complying with the government policies. Hence in many cases the government opted to use coercive means and instruct people to obey and follow the government policies. This was one of the factors that contributed to the complications of implementing the policy, accordingly the villagization policy. On the other hand, some writers blame the rich farmers, some government officials and party officials for not showing interest in the policy and development in general. The rich farmers were reluctant to participate in communal production. Yet, the government and party officials were not fully committed assisting in developing the Ujamaa villages.

Despite of Ujamaa policy achieving in enhancing unity and solidarity among the people, however, it brought poverty as much of the country resources were invested in the implementation of the policy which later proved failure. However, there were only few rich peasant and government officials who used the policy to private gain. Henceforth social inequalities existed between the poor and the rich. As Nyerere admitted as much in one of the speeches in which he reflected on the progress made by Ujamaa policies after ten years. Nyerere states that:

"Ten years after the Arusha Declaration Tanzania is certainly neither socialist, nor self-reliant. The nature of exploitation has changed, but it has not been altogether eliminated. There are still great inequalities between citizens. Our democracy is imperfect. A life of poverty is still the experience of the majority of our citizens" (Nyerere,1968).

The mismanagement of funds shows that the Ujamaa policy did not fail but the people who were in charge in the villages were corrupt. They were only enriching themselves. And some of the villages wanted to become Ujamaa villages in order to benefit from the Ujamaa projects only, rather than building and developing the country and our citizens" (Nyerere,1968).

Socialism ideology not only influenced the forms of power and knowledge in all spheres of human life, but also it influenced the aesthetic production of such texts [Summons] in literary scholarship. This concurs to what Eagleton (1983) asserted that not only the ideological character of the society is tied to literary text but also it its history as well as its production. Thus, it is difficult to overlook the history of Tanzania in a context of discourse of representation of Tanzanian socio-political realities through poetry (Mwaifuge \& Omigbule, 2016). In fact, Art has a particular relationship to ideology that in turn signifies the imaginary ways in which men experience the real world, which is obviously, the kind of experience literature gives us too-what it feels like to live in particular conditions, rather than a conceptual analysis of those condition (Eagleton, 1983). Eagleton (1983) added that literary works are not mysteriously inspired, or explicable simply in terms of their authors' psychology. Rather, they are forms of perception, particular ways of seeing the world; and as such they have a relation to that dominant way of seeing the world which is the 'social mentality' or ideology of an age". Thus, literary text [Summons] was influenced with its mode of production [socialism ideology or era]. Here, the stress is on interconnectedness' between Art [Summons] and modes of production [socialism] and how the two concepts merge to uncover 
the worldview (Ng'umbi, 2015). Therefore, Summons, the first Tanzanian poetic anthology in English contain poems that are social critique or satire in the unrestricted sense. The poems are, therefore, as would be expected, about problems of building socialism. They are about and against the ideologies which confuse the vision people have of themselves and of their lives. Given the historical event and social condition of the Author's society, I argue that the rise of Socialism ideology consolidated the birth of Summons and thus the authors' worldview expressed in the poems echoes the society's global structure [socialism philosophy]. Poems in this category includes:

"Saluting Ujamaa" (Mabala, 1980,p. 59-61) by Kundi Faraja, whereas the poet praises the ideology and presents it as a solution to the economic depression of post-independent Tanzania. Through the persona, the poem glorifies the ideology, by referring to the advocate of the ideology, Nyerere. The poem portrays a persona whose wish is to see the ideology become part and parcel of the Tanzanian and weaken imperialism. The poem creatively put use of metaphor of lump and Ugali to portray Ujamaa policy as a solution to the economic problems of the country. Equally, images of elephants and buffalo are employed to reveal the strength of the ideology. The following lines provide an exemplification of how the persona praises the ideology;

I salute you,

Ujamaa,

You are a lump

Of Ugali.

Stuck

In the throat

Of a man,

Product of the colonial times:

He can neither vomit nor swallow.

Bull elephant of Ujamaa,

Don't strange me.

I surrender.

Karibu,

Enter my stomach

And, mind you;

Bring, me new life

I want to adjust myself

To Ujamaa (59)

On the other hand, the poem mirrors the subsequent historic nationalization policy, which aimed at nationalizing all existing resources and abolishing the capitalist regimes in the society: leading to public ownership of the major means of production (Mwaifuge \& Omigbule, 2016; Yona, 2008).The poem questions about the policy's slogan [relating to private property ownership] during Ujamaa era. The poem tri es to depict, people, especially leaders, were evaluated based on their record of integrity, and the leadership code forbade owning of property as it could "open the door for a few individuals to exploit their fellow human beings" (Peter, 2011).The poem ironically portrays the paradox which was raised during the Ujamaa era. The ideology dampens private ownership of property while inspires people to be 
Mihayo, Manuaba, EduLite: Journal of English Education, Literature, and Culture Vol.4, No.2, August 2019, 171-182 DOI: http://dx.doi.org/10.30659/e.4.2.171-182

self-reliant. The following lines provide an exemplification of the incongruities that subverted the operation of the ideology. As the persona says:

I have a bar,

A hotel,

A butcher's shop,

All mine

And mine alone.

Tell me,

Ujamaa,

Perfect system,

What do I do...? (68-70).

The above citation displays the weakness of Ujamaa and hence lacked popular support, thus made difficult to implement the ideology. This is more evident in the poem as the persona embraces Ujamaa because of its good promises on one hand and is also impressed of capitalism on the other hand. The persona is interested in Ujamaa, but he cannot inherit it because of the restriction it imposes to his private gain. For this reason, the poem simply portrays Ujamaa as unfeasible since people remains individualistic upon which capitalism itself is founded.

Another poem that creatively questions the operability of the common socialist ideology is Mabala's “The Socialist" (Mabala, 1980, p. 44-46).The poem includes three different persona, who equally demurs the socialist ideology called Ujamaa. The poem shows a persona who is well experienced in the principles of Ujamaa. The following is a piece of the poem indicating the case in point:

"I am a socialist," he muttered gently

Sinking softly into the sighing depths

Of the cushioned chairs

Of the Kilimanjaro

"Traditional

African Socialism

Work by all for the good of all.

"Socialism is an attitude of mind,"

He continued

Gazing lovingly at the golden whisky in his glass

"I am a peasant

And a worker

We must all sacrifice to build this great nation of ours" (p.44)

Building on the persona's view it is shown that, regardless of the declaration of socialist ideology, the ideal is far from being achieved as exposed in the poem, "The Socialist" (Mabala, 1980). The persona's expression "the golden whisky in his glass," contradicts with her or his self-proclaimed socialist belief. As the appearance bears no more than a capitalist presence in the life of a socialist. Thus, this showcase the discrepancy between what has been proclaimed by the followers of Ujamaa and what exactly was done by them. Nevertheless, the ideology advocates for unity and teamwork among the people. But the poem illustrates the stentor of the ideology whose face wears the capitalist ideology. This acknowledges that majority were not supportive of 
Ujamaa despite the hope expressed in the last stanza of the poem, "we must all sacrifice to build this great nation of ours".

Actually, individualism and irresponsibility made by some government officials dented the benevolence that was supposed to be fostered under Ujamaa. Thus, Ujamaa was considered idealistic and unrealistic. Ibhawoh and Dibua (2003, p. 15)comments that, "Ujamaa policies unmitigated failure and that under Nyerere, Tanzania's economic progress was distorted, and resources wasted in the slavish adherence to ideology: giving rise to a marginalized rural sector and a corrupt and inefficient bureaucracy [...]".Faraja's poem "Live and Let Die" critically illustrates two classes in the society that were formed after Ujamaa. The first group enjoys the national cake while the second group is of poor people who own nothing. As the poet says:

..Because the rich man

Is not yet read

To die a little

So that the poor man may live

The quotation display case the nature of exploitative relationship existing in the society. Whereas the rich exploits the poor in all scopes of life. The poem also describes the poor living condition in which people live that reflects in their physical structure of the society. The poem creatively employs imageries of "dwarf, soiled, rags, abandoned hut" to shows poverty in the society. On the poem the persona says:

Let them drink water

Let them eat air

Let them digest the sunshine

Because that is what

I can afford to buy

...that they don't have good health

That they wear rags.

The poem wits rich people by saying, "let them digest the sunshine because that is what I can afford to buy" to describes how people could not afford the basic needs in Tanzania during and after Ujamaa period whilst the rich and some leaders are living luxurious life.

Furthermore, in the three poems discussed so far, "Saluting Ujamaa", "The Socialist", and Live and Let Die" revealed that Ujamaa was a difficult scheme to achieve, because of falsehood and disinterest shown towards it by the majority through the poem; that is, what Peter (2011) has showed as low reception of it "as the ideal ideology for the development of the society" (Mwaifuge \& Omigbule, 2016). After all, this might be due to the wicked approach used by the socialist in executing the ideology. For example, the villagization method of Ujamaa infuriated the peasants. Appropriately, majority began to hate Ujamaa and blamed the government and the President in particular for its downfalls. The situation was followed by the economic stagnations in which Tanzania found herself in the latter years. This dynamics of the Tanzanian history (worldview) is creatively validated in the poems under study. As the contributors of the poems are Tanzanian [brought out by the ferment of socialism] then they have creatively represented the worldview of Tanzanian society during and after the Ujamaa era. As a matter 
Mihayo, Manuaba, EduLite: Journal of English Education, Literature, and Culture Vol.4, No.2, August 2019, 171-182 DOI: http://dx.doi.org/10.30659/e.4.2.171-182

of fact, the poems' structure exclusively reflect the world vision held by the writer. This implies that there is a relationship between the worldview as a reality which happened in Tanzania during and after socialism and the author world of creation and literary tools in the poems. Thus, the author's worldview corresponds with the society's structure.

\section{CONCLUSION}

As it can be deduced from the analysis, socialism is not seen as a mere ideology in Tanzanian history; it, however, appears as a major worldview in Tanzanian poetry in English which in turn reflects the Tanzanian postindependence society between 1960 s to 1980 s. In addition, worldview is very important in literary works as it reveals the social and historical realities happening from which the text was produced. Notably, it is held that worldview is never stable as it always in the process of being structured or restructured. Henceforth changes in society's structure influences also changes in the constituent elements of the literary text. As a result, structure of the text changes too. This has been the same case with Tanzanian poetry in English. As Summons represent an earlier generation of Tanzanian poets who were brought up by the ferment of Ujamaa policy, they were basically dedicated to Ujamaa because of the major impact the ideology had on the lives of Tanzanian. Conversely, the later generation of Tanzanian poets in English like Shilia Kaaya, Charles Muloka, and Neema Komba- adjust the orientation and focus of their poems very much in keen with changing political and economic scene in Tanzania. Their major concern is with global issues as they relate Tanzania as a point of interest. They address global issue like democracy, globalization, HIV/AID and others. For example, Neema Komba in her poem "My Democracy'. The poem uses simple and straight language that represents crucial issue about democratic election in contemporary African countries. The persona says, "When will I begin to matter" questioning when will African countries start to conduct fair and free elections. Therefore, author's worldview changes as the global structure of its society changes and in fact the social and historical discourse influences the production of such text too. As Goldmann (1980) contends that the, "the relations between the truly important work and the social group, which-through the medium of the creator- is, in the last resort, the true subject of creation, are of the same order as relations between the elements of the work and the work as whole". In both cases, we deal with the totality, the literary work as a living whole which is understood in terms of its constituent structures. It is a to and fro, from the whole to the parts and the parts to the whole again, a course of movement in which the whole and the parts shed light upon one another (Goldmann, 1980; Laurenson \& Swingewood, 1972; Zubaidi, 2011). Thus, forms the authors' worldview depicted in selected poems. 


\section{REFERENCES}

Belsey, C. (2013). Textual Analysis as a Research Method.Research Methods for English Studies.(G.Griffin, Ed.) (2 ${ }^{\text {nd }}$ Edition). Edinburg: Edinburg University Press. Retrieved from https://www.jstor.org/stable/10.3366/j.cttg0b4xz.12

Berg, B. L. (2012). Qualitative Research Methods for the Social Sciences (7th edition). Boston: Pearson.

Creswell, J. . (2013). The Selection of a Research Approach. Research Design: Qualitative, Quantitative, and Mixed Methods Approaches (2nd edition). London: SAGE Publication.

Eagleton, T. (1983). Literary Theory: An Introduction (2nd editio). Oxford: Blackwell Publishers Ltd.

Endraswara, S. (2013). Metodologi Penelitian Sastra. Yogyakarta: CAPS (Centre for Academic Publishing Service).

Goldmann, L. (1980). Essays on Methods in the Sociology of Literature. (William Boelhower, Ed.). St. Louis, Mo: Telos Press Ltd.

Ibhawoh, B., \& Dibua, J. I. (2003a). Deconstructing Ujamaa: The Legacy of Julius Nyerere in the Quest for Social and Economic Development in Africa. African Journal of Political Science, 8(1), 59-83 https: //doi.org/10.1.1.477.613

Kelleher, B. (2000). Iron Star. New York: Jove Book.

Lal, P. (2010). Militants, mothers, and the national family: Ujamaa, gender, and rural development in postcolonial Tanzania. Journal of African History, 51(1), 1-20. Retrieved from https://doi.org/10.1017/S0021853710000010.

Laurenson, D \& Swingewood, A. (1972). The Sociology of Literature. London: Granada Publishing Limited.

Mabala, R. (1980). Summons: Poems from Tanzania. Dar es Salaam: Tanzania Publishing House.

Makulilo, V. B. (2012). Where is socialism in Tanzania? Elixir International Journal, 46, 8170-8180. Retrieved from www.elixirpublishers.com

Mkunde, B. M. (2014). The culture of self-reliance and foreign aid to least developed countries: the case of mosquito bed nets distribution in tanzania, 5(2).

Mwaifuge, E \& Omigbule, M. (2016). Thematic Concerns of Tanzanian Poetry in English. IFE studies in english language (isel)journal of the department of English, Obafemi Awolowo University, Ile-Ife,Nigeria, 12(2), 153-173.

Ng'umbi, Y. C. (2015). Politics of the Family in Contemporary East and West African Women's Writing. Unpublished PhD Dissertation. Faculty of Arts and Social Sciences: Stellenbosch University. Retrieved from Stellenbosch University https://scholar.sun.ac.za

Nyerere, J, K. (1968). Ujamaa: Essays on Socialism. Nairobi: Oxford University 
Press.

Orwell, G. (1945). Animal Farm: A Fairy Tale. United Kingdom: Warburg.

Peter, J. (2011). "The Representation of Tanzania's Society during Ujamaa and the Prediction of Tanzania's Future in Selected Poems in Summons". Unpublished M.A Dissertation. University of Dar es Salaam.

Rivkin, J. and Ryan, M. (2004). Introduction: Feminist Paradigms (Eds.,Eds.,). London: Blackwell Publishers Ltd.

Selden, R., Widdowson, P., \& Brooker, P. (2016). A Reader's Guide to Contemporary Literary Theory (6th Edition). Lexington, Kentucky: Routledge.

Sheikheldin, G. H. (2015). Ujamaa: Planning and Managing Development Schemes in Africa, Tanzania as a Case Study. The Journal of Pan African Studies, 8(1), 78-.

Wakota, J. (2014). The Making and Remaking of Gender Relations in Tanzanian Fiction.Unpublished PhD Dissertation. Faculty of Arts and Social Sciences: Stellenbosch University.

Wakota, J. (2016). Ujamaa's villagization and gender dynamics in selected Tanzanian fiction. Journal of African Cultural Studies, 30(1), 49-64. https://doi.org/https://doi.org/10.1080/13696815.2016.1207158

Witri Nur'aini. (2009). Genetic structuralism analysis on "lucky jim" by kingsley amis. Unpublished B.A Thesis. English Letter Department: State Islamic University "Syarif Hidayatullah."

Yona, M. (2008). "Popular Histories of Independence and Ujamaa in Tanzania.Unpublished M.A Thesis. Department of History: University of the Western Cape.

Zubaidi. (2011). Kelleher's World View on Iron Star Novel: The different point of view in seeing terrorism " (A Genetic Structuralism Research).Unpublished B.A Thesis. FACULTY OF LANGUAGES AND ARTS. Semarang State University. 